Agata Lipińska

Uniwersytet Jagielloński

aga.lipinska@student.uj.edu.pl

\title{
Fenomen współczesnych seriali. O społecznym oddziaływaniu seriali telewizyjnych
}

\author{
The phenomenon of present-day TV series. On the social impact of television \\ drama
}

Abstract: This article is an attempt to determine the source of the immense popularity of serial narratives, which can be observed in recent years, as well as to present mechanisms underlying the attractiveness of the TV series to their audiences. The purpose of the text is to identify common elements between literature and episodic television production, leading to a conclusion that there is an overlapping in the functions of both types of cultural texts.

Keyword: TV series, quality television, culture of convergence, active recipient

Streszczenie: Artykuł jest próbą dotarcia do źródeł ogromnej popularności narracji seryjnych, z jaką mamy do czynienia w ostatnich latach, a także przedstawieniem mechanizmów wpływających na atrakcyjność seriali dla ich odbiorców. Tekst ma na celu wskazanie elementów wspólnych między literaturą a telewizyjnymi fabułami odcinkowymi prowadzące do sformułowania wniosków o nakładaniu się społecznych funkcji tekstów kultury pochodzących z obu dziedzin.

Słowa kluczowe: serial telewizyjny, telewizja jakościowa, kultura konwergencji, odbiorca aktywny

Serial telewizyjny jest obecnie uważany za najpowszechniejszą formę audiowizualną. Chciałabym tu wyjaśnić, skąd bierze się popularność seriali oraz jak ważne i różnorodne funkcje społeczne pełnią te teksty kultury. Mówi się, że mamy dzisiaj do czynienia z trzecią złotą erą telewizji - pierwsza przypadała na lata pięćdziesiąte, druga zaś to okres pomiędzy początkiem lat osiem- 
dziesiątych a połową lat dziewięćdziesiątych ${ }^{1}$. Formuła serialu i sposób przedstawiania zmieniły się w tym czasie bardzo wyraźnie. To typ programu, który dezaktualizuje się bardzo szybko w porównaniu z innymi tekstami kultury. W ciągu ostatnich dwudziestu lat liczba takich produkcji zwiększyła się kilkanaście razy, szczególnie na Zachodzie. Jak to bywa z tworami popkultury, tak i w tym wypadku wciąż rosnące zainteresowanie serialami wpływa na powstawanie nowych fabuł mających ambicje, by zerwać z niewolniczym kopiowaniem sprawdzonych wzorców. Każda znacząca stacja w okresach zmiany ramówki stara się zaprezentować swojej widowni kilka nowych propozycji serialowych. Dla przykładu stacja ABC w sezonie 2015/2016 zaproponowała swoim widzom po cztery zupełnie nowe pozycje komediowe i dramatyczne. Ta sama stacja, licząc tylko od roku 2010, anulowała emisję 27 seriali po pierwszym sezonie. $\mathrm{Z}$ nowymi serialami jest trochę tak jak z kulami w grze losowej. Twórcy przypominają graczy, którzy wybierają, na co warto postawić, ale nie mają wpływu na to, co zostanie wylosowane. Widzowie zaś są jak maszyna losująca, która z wielu propozycji wybiera pojedyncze produkty. Stacje starają się więc zaproponować jak najwięcej, jak najbardziej nieszablonowych programów, by zwiększyć swoje szanse w grze o wysoką stawkę, jaką jest uwaga odbiorców. Zatem jak w przypadku innych tworów popkultury jeśli na coś jest popyt, to musi być też podaż. Owej tendencji ilościowej towarzyszy na szczęście tendencja jakościowa. Do niedawna produkcje telewizyjne postrzegano jako te gorsze $\mathrm{w}$ stosunku do powszechnie uznanych filmów kinowych. Teraz wystarczy obejrzeć kilka odcinków popularnych seriali, by przekonać się, jak wielka nastąpiła zmiana. Za tym, że seriale już dawno przestały być produktami drugiej kategorii, przemawia również fakt bajońskich sum przeznaczanych na ich realizacje. Dla przykładu budżet pilotażowego odcinka „Zakazanego imperium” ${ }^{2}$ sięgnął 18 milionów dolarów, kolejnych zaś średnio 5 milionów ${ }^{3}$. Nie jest to wcale odosobniony przypadek. Oczywiście nie twierdzę, że wszystko, co drogie, musi być wartościowe. Chodzi mi raczej o pokazanie, jak bardzo podobny do produkcji kinowych staje się serial. Cechują go szczegółowo dopracowane plany filmowe, niesamowite efekty specjalne, starannie dobrani aktorzy, a także świetnie skonstruowane scenariusze (napisane niejednokrotnie przez scenarzystów filmowych). Jak konstatuje Sarah Cardwell:

Nie chodzi o to, że konkretne tempo, styl pracy kamery, poziom szczegółów w reżyserii, typ gry aktorskiej lub konkretny zbiór motywów czynią program dobrym -

${ }^{1}$ R.J. Thompson, Television's Second Golden Age: From „Hill Street Blues” to „ER”, New York 1996, s. 11-13.

2 „Zakazane imperium” („Boardwalk Empire”, HBO, 2010-2014).

3 J. Lebioda, Najdroższe seriale wszechczasów. Zaskakująca czotówka, http://life.forbes.pl/ ranking-najdrozszych-seriali-w-historii,artykuly, 194157,1,1.html, dostęp: 1.03.2016. 
choć te aspekty mogą uczynić go jakościową telewizją - ale o to, że sposób, w jaki te aspekty są ze sobą połączone, może wytworzyć stylistycznie spójną całość .

To wszystko pochłania ogromne koszty, których twórcy nie boją się ponieść, gdyż wiedzą, że ich wysiłki zostaną nagrodzone, jeżeli tylko zwróca uwagę publiczności. Powoduje to powstawanie produktów wysokiej jakości, których odbiór staje się czymś atrakcyjnym, a w pewnych kręgach nawet wymaganym i koniecznym. Szczególnie w ostatnim czasie, kiedy mamy do czynienia z prawdziwą modą na seriale. To zjawisko bardzo trafnie określił Grzegorz Wysocki, nazywając je „chroniczną serialozą”:

Od kilku lat cierpię na coś, co na potrzeby tego tekstu będę nazywał chroniczną serialozą. I pewnie nie byłoby za bardzo o czym mówić i czym się chwalić, gdyby nie fakt, że od jakiegoś czasu mamy do czynienia z prawdziwą epidemią. Postępująca serialoza zatacza coraz szersze kręgi, nie sposób przed nią uciec i bezpiecznie się ukryć, infekuje i zniewala nawet najbardziej do tej pory o(d)pornych (m.in. profesorów akademickich, klasycyzujących pisarzy, stałych bywalców filharmonii czy zdeklarowanych przeciwników „telewizyjnej sieczki”, w których salonie nigdy nie stanie żaden telewizor) $)^{5}$.

Ostatnie zdanie jest szczególnie istotne, ponieważ pokazuje przemianę, jaka nastąpiła w sposobie postrzegania serialu w ogóle. Przyznanie się, zwłaszcza w środowisku tych „o(d)pornych”, do oglądania popularnych serii nie jest już powodem do wstydu, lecz stanowi doskonały pretekst do wymiany spostrzeżeń, chociażby na temat ostatniego odcinka. Współcześnie to właśnie ambitne seriale zajęły miejsce powieści realistycznych i stanowią doskonały materiał do rozważań o otaczającym nas świecie, stąd prawdopodobnie zainteresowanie przedstawicieli wyżej wymienionych grup. W dalszej części swojego tekstu Wysocki zauważa, że jesteśmy współcześnie świadkami ogromnej przemiany w serialach. Nie mogę się jednak do końca zgodzić ze stwierdzeniem, iż owa zmiana jest „w mniejszym stopniu - ilościową, w dużo większym jakościową" ${ }^{6}$. Mam wrażenie, że przemiana ilościowa jest równie wyraźnie zauważalna jak jakościowa. W ostatnich latach, w związku z postępującą globalizacją i szybkim rozwojem nowych technologii, obserwujemy widoczny wzrost podaży nad popytem, szczególnie w wypadku omawianego tekstu kultury ${ }^{7}$.

${ }^{4}$ S. Cardwell, Czy telewizja jakościowa jest dobra? Różnice gatunkowe, oceny oraz ktopotliwa kwestia krytycznego osądu, tłum. D. Kuźma [w:] Zmierzch telewizji? Przemiany medium. Antologia, red. T. Bielak, M. Filiciak, G. Ptaszek, Warszawa 2011, s. 142.

5 G. Wysocki, Epidemia chronicznej serialozy, dwutygodnik.pl 2001, nr 6, http://www. dwutygodnik.com/artykul/2395-epidemia-chronicznej-serialozy.html, dostęp: 30.03.2016.

6 Tamże.

7 W. Piątkowski, Marketing telewizji, czyli dlaczego tylko niektóre seriale odnosza sukces [w:] Post-soap. Nowa generacja seriali telewizyjnych a polska widownia, red. M. Filiciak, B. Giza, Warszawa 2011, s. 208. 
Jednakże z punktu widzenia obranej perspektywy badawczej przemiana jakościowa wydaje się o wiele bardziej istotna. To ona wpłynęła na to, że popularnych obecnie serii z gatunku quality tv nie możemy tak łatwo zrównać $\mathrm{z}$ „telewizyjną sieczką”, produkowaną przez kulturę masową. Sklasyfikowanie ich jako telewizyjnego fast foodu, który odbiorca pochłonie bez konieczności odrobiny refleksji, byłoby dla nich i ich autorów ogromnie krzywdzące. Wspomniane programy zbliżają się coraz bardziej do poważnego kina, adresowanego do świadomego i wymagającego widza. To zjawisko bardzo trafnie opisał Grady Hendrix:

Nagle oczekuje się od nas, że nie tylko będziemy oglądać, lecz także czytać eseje, rozmyślać i dyskutować o trwających godzinę odcinkach serii dramatycznych (...). Oglądanie tych programów jest jak dołączenie do masonerii: wymaga zapamiętywania tajemniczych drobiazgów, analizowania zagadkowych zwrotów akcji oraz niemal fanatycznej lojalności. Nie możemy po prostu ich oglądać - musimy być im oddani w taki sposób, w jaki John Hickley był oddany Jodie Foster

Skąd jednak bierze się potrzeba śledzenia fabuł odcinkowych? Powodów może być wiele. Wydaje mi się, że obecna popularność seriali ma cztery źródła. Pierwszym z nich będzie chęć doświadczenia nieznanego w bezpiecznej formie. Jak zauważają autorzy we wstępie do książki Seriale z różnych stron, człowieka cechują dwie sprzeczne cechy: neofilia i neofobia'. Z jednej strony jest on bowiem istotą ciekawą świata, pragnącą rozwoju i nowości, z drugiej zaś obawiającą się tego, co może ją czekać w kontakcie z nieznanym. Dlatego też seriale stały się idealnymi tworami realizującymi oba, pozornie sprzeczne, elementy. Pozwalają na bezpieczne doświadczanie czegoś nowego, przy jednoczesnym zachowaniu kontaktu z czymś znanym. Można to określić jako oglądanie „nowej, wciąż tej samej historii" ${ }^{10}$. Wydawać by się mogło, że sprawa ma się inaczej w wypadku programów quality $t v$. Wcale jednak tak nie jest. To prawda, że odbiorca oczekuje od nich emocji, zaskoczenia i wzruszeń, jednak otrzymuje je wciąż w bezpiecznej formie. Prezentowane fabuły nie są przewidywalne w tym sensie, że wiemy, co się za moment wydarzy i jak oglądana historia się zakończy. Kategoria przewidywalności dotyczy tutaj świadomości stale możliwego powrotu do sytuacji wyjściowego ładu. Owe seriale, owszem, poruszają mocniej niż wcześniejsze produkcje, niemniej zawsze pozostaje ta sama droga ucieczki. Choćby widz oglądał najbrutalniejsze sceny, wie, że po wyłączeniu ekranu wraca z powrotem do swojej bezpiecznej rzeczywistości.

${ }^{8}$ Cyt. za: G. Wysocki, dz. cyt.; w cytacie: John Hickley, właśc. John Hinckley.

9 J. Grębowiec, A. Lewicki, Wstęp [w:] Seriale z różnych stron, red. A. Lewicki, J. Grębowiec, Wrocław 2015, s. 7.

${ }_{10}$ Tamże. 
W dzisiejszym niespójnym, „zabieganym” świecie człowiek potrzebuje elementów stałych. Zatem kolejne źródło popularności serialu możne być upatrywane właśnie w zaspokajaniu tej potrzeby. Telewizyjne serie doskonale się do tego nadają. Te emitowane w rodzimej telewizji dają widzowi poczucie bezpiecznej rutyny, ponieważ ma pewność, że konkretnego dnia o wiadomej godzinie zobaczy dalszy ciąg ulubionej historii. W wypadku seriali starego typu nawet sam tok akcji jest w znacznym stopniu przewidywalny. Dobrym przykładem będzie tutaj produkcja Telewizji Polskiej - „Ojciec Mateusz”" Odbiorca od samego początku wie, kto jest dobry, a kto zły. Ma również świadomość, że ten pierwszy zawsze zatriumfuje i przywróci utracony ład. Gdy zaś spojrzymy na omawiane seriale, stwierdzimy, że przewidywalność mieści się paradoksalnie w ich nieprzewidywalności. Widz, oglądając, ma nadzieję, że znów przeżyje coś, czego już doświadczył, dzięki czemu „wciągnął się" w oglądanie właśnie tego serialu. Liczy na niekończące się zaskoczenie. Dlatego też w negatywnych recenzjach zbyt długo ciągniętych serii często pojawia się zarzut, że już nie zaskakują. Widz podświadomie wręcz liczy na to, że zdarzy się coś, co zachęci go do obejrzenia kolejnego odcinka. Stąd często stosowany przez twórców cliffhanger, czyli zabieg zawieszenia akcji w najbardziej emocjonującym momencie. Na przykład w zakończeniu ostatniego odcinka czwartego sezonu „Dextera” (czyli w momencie, w którym w wypadku seriali tradycyjnych powinno nastąpić wyjaśnienie wszystkich poruszonych wątków i przywrócenie ładu) bohater znajduje ciało zamordowanej żony ${ }^{12}$. Zabieg pozostawiania widza z mnóstwem pytań, bez prawie żadnych podpowiedzi jest dość często stosowany przez scenarzystów współczesnych seriali.

Trzecim źródłem opisywanego zjawiska będzie łatwy dostęp do seriali. Odbiorca może się oddawać przyjemności doświadczania ulubionych fabuł, kiedy tylko ma na to ochotę. Nie musi się dostosowywać do godziny emisji, planować wyjścia do kina, martwić się dojazdem lub pogodą. Obcowanie z tym tekstem kultury nie wymaga nawet wyjścia $\mathrm{z}$ domu, a wyczekiwaną premierę możemy obejrzeć, gdy tylko mamy na to ochotę, sącząc herbatę z ulubionego kubka. Dzięki platformom, takim jak chociażby Netflix, subskrybenci mają dostęp do seriali w nieograniczonym wymiarze. W ostatnim czasie nawet najnowsze sezony takich serii, jak na przykład „House of Cards” ${ }^{13} \mathrm{i}$ „Daredevil” ${ }^{14}$, udostępniane są jako całości. Stawia to współczesny serial bliżej serii powieściowych niż historii odcinkowych drukowanych w prasie, ale o tym później.

Popularność seriali wynika też z powolnej demokratyzacji wpływów producentów i widzów. Serial nie tylko oddziałuje na swojego odbiorcę, ale także odbiorca (lub raczej grupa odbiorców - fanów) coraz częściej ma wpływ na

11 „Ojciec Mateusz” (TVP, 2008-).

12 „Dexter” („Dexter”, Showtime, 2006-2013), sezon 4, odcinek 12 „The Getaway”.

13 „House of Cards” („House of Cards”, Netflix, 2013-).

14 „Daredevil” („Daredevil”, Netflix, 2015-). 
sam serial. To wyraźne oddanie ogromnej części władzy w ręce widzów jest niezwykle istotne. Henry Jenkins w książce Kultura konwergencji. Zderzenie starych i nowych mediów tak pisze o przemianach zachodzących wśród konsumentów popkultury:

Konwergencja ${ }^{15} \mathrm{zmusza}$ firmy medialne do ponownego przemyślenia starych koncepcji tego, czym jest konsumpcja mediów - koncepcji, które kształtują zarówno decyzje programowe, jak i marketingowe. $\mathrm{O}$ ile starych konsumentów postrzegano jako pasywnych, o tyle nowi są aktywni. Dawniej byli przewidywalni i zostawali tam, gdzie kazano im zostać, teraz migrują, nie zachowują lojalności wobec stacji czy mediów. Starzy konsumenci byli odizolowanymi jednostkami - nowi nawiązują silniejsze związki społeczne. Jeśli praca konsumentów była kiedyś cicha i niewidzialna, dziś są hałaśliwi i wszechobecni ${ }^{16}$.

Oczywiście, jak to bywa w wypadku obalania każdej dyktatury, producenci mogą buntować się i nie godzić na dzielenie wpływami. Jednak takie działania bardzo szybko przynoszą negatywne skutki. Zlekceważony odbiorca może zrezygnować z oglądania serii i po prostu wybrać inną propozycję. A gdy raz odejdzie do innego programu czy produktu, bardzo często już nie wraca. Twórcy popkultury po prostu nie mogą sobie na to pozwolić, więc podział władzy jest dla nich nieuchronną koniecznością.

Nowy widz nie okazuje się już biernym konsumentem, bezrefleksyjnie „wgapionym” w migający ekran. Niezmiernie istotny wydaje się fakt, że jego płaszczyzną działania jest internet. Nie boi się krytykować realizacji, które obejrzał, ponieważ jest na tyle kompetentny, by to zrobić. Dzięki rozwojowi nowych technologii może publikować swoje analizy i komentarze, a także wymieniać się spostrzeżeniami z innymi fanami tego samego tekstu kultury:

Fani popularnych programów telewizyjnych mogą samplować dialogi, pisać streszczenia odcinków, dyskutować o podtekstach, tworzyć własne opowiadania fan fiction, nagrywać własne ścieżki dźwiękowe i kręcić swoje filmy - dystrybuując to wszystko na cały świat poprzez Internet ${ }^{17}$.

Fani łączą się w większe grupy, zwane fandomami. Tym mianem określa się grupę aktywnych odbiorców skupionych wokół tego samego tekstu kultury. Nie tylko identyfikują siebie jako fanów, ale także uważają się za część

15 „Jako konwergencję rozumiem przepływ treści pomiędzy różnymi platformami medialnymi, współpracę różnych przemysłów oraz migracyjne zachowania odbiorców mediów, którzy dotrą niemal wszędzie, poszukując takiej rozrywki, na jaką mają ochotę. Konwergencja to pojęcie opisujące zmiany technologiczne, przemysłowe, kulturowe i społeczne”. H. Jenkins, Kultura konwergencji. Zderzenie starych i nowych mediów, tłum. M. Bernatowicz, Warszawa 2007, s. 9.

16 Tamże, s. 23-24.

17 Tamże, s. 21. 
większej społeczności. Mamy tu do czynienia ze wspólnototwórczą rolą popkultury. Widzowie tego rodzaju coraz głośniej domagają się wpływu na ukochane produkcje, więc twórcy wychodzą im naprzeciw, organizując specjalne spotkania i konwenty, które pozwalają odbiorcom na podjęcie dialogu już nie tylko z samym tekstem kultury, ale i z jego autorami ${ }^{18}$.

Nie można jednak przyjąć, że funkcjonuje obecnie tylko i wyłącznie postawa aktywnego odbiorcy. Byłoby to nadużycie, ponieważ bierni widzowie, przyjmujący bezrefleksyjnie telewizyjny strumień, istnieją i mają się dobrze. Jednak grupa aktywnych konsumentów staje się coraz liczniejsza. Bierny odbiorca zwyczajnie nie wychwyci nawiązań do innych tekstów kultury (koniecznych do lepszego zrozumienia całości), a w zagmatwanych, wielowarstwowych narracjach zwyczajnie się pogubi. Sfrustrowany wróci więc do dobrze mu znanych i prostych w odbiorze obyczajowych „tasiemców” i niezobowiązujących sitcomów.

Oglądanie ulubionych serii nie jest już tylko sposobem na relaksujące spędzenie wolnego czasu. Bernadetta Darska wyróżnia trzy mechanizmy wpływające na popularność seriali ${ }^{19}$. Pierwszym z nich jest okazja do podglądania świata niedostępnego, niemożliwego do poznania w ramach własnej rzeczywistości. Współcześnie nie chodzi już o fascynację, nieosiągalnym dla większości, życiem bogaczy, jak to się działo w latach osiemdziesiątych i dziewięćdziesiątych ${ }^{20}$. Dla polskiego odbiorcy w owym czasie takie fabuły miały wymiar niemal baśniowy ${ }^{21}$. W serialach obyczajowych widz obserwował życie prywatne bohaterów - ich problemy rodzinne, miłosne, zdrowotne, rzadko zawodowe. Inaczej sprawa ma się w wypadku seriali „branżowych”. Dzięki wybranej opowieści odcinkowej odbiorca zyskał możliwość obserwacji pracy zawodów, do których nie ma dostępu w prawdziwym życiu. Przeciętny Kowalski nie zostanie wpuszczony na salę operacyjną w trakcie trwania operacji (chyba że zabieg jest przeprowadzany na nim). Podobnie w wypadku pracy policji. Nie będzie mógł uzyskać dostępu do materiału dowodowego i tajników działań

${ }_{18}$ Zob. A. Włodarczyk, Wptyw realny czy wyobrażony? Fanowskie poczucie wptywu na seriale „Sherlock" $i$ „Nie z tego świata" [w:] Seriale w kontekście kulturowym: gatunki, konwergencja, recepcja, red. A. Krawczyk-Łaskarzewska, A. Naruszewicz-Duchlińska, P. Przytuła, Olsztyn 2014, s. 220.

19 B. Darska, Zamiast wstępu [w:] tejże, To nas pociaga! O serialowych antybohaterach, Gdańsk 2012, s. 5.

${ }^{20}$ Mam tu na myśli ogromną popularność takich seriali, jak „Dynastia” („Dynasty”, ABC, 1981-1989) i „Moda na sukces” („The Bold and the Beautiful”, CBS, 1987-) ukazujących perypetie przedstawicieli amerykańskiej klasy wyższej.

${ }^{21}$ Ten temat został poruszony w rozmowie Krzysztofa Tomasika i Kingi Dunin, stanowiącej wstęp do książki Seriale. Przewodnik Krytyki Politycznej:

„Krzysztof Tomasik: (...) Jak rozumiem, to był powiew lepszego świata - jacyś piękni ludzie, taki świat luksusu. Kinga Dunin: W ogóle - bajka. W bajkach wszystko bywa piękne. Nie przychodziło mi do głowy, żeby porównywać rzeczywistość z serialem”. K. Dunin, K. Tomasik, 101 seriali [w:] Seriale. Przewodnik Krytyki Politycznej, red. Zespół Krytyki Politycznej, Warszawa 2011, s. 6. 
organów ścigania. Na temat głośnej zbrodni dowie się tylko tyle, ile zostanie przekazane mediom. Oczywiście, nie mając specjalistycznej wiedzy, odbiorca nie potrafi zweryfikować, czy ma do czynienia z wiernym odwzorowaniem rzeczywistości, czy też z całkowitą fantazją twórców. Jednak uprawdopodobnienie działań profesjonalistów poprzez zastosowanie fachowego nazewnictwa oraz realistycznych planów zdjęciowych służy widzowi za wystarczający dowód. Serial daje możliwość zaspokojenia ciekawości - pokazuje to, co dzieje się zwykle za zamkniętymi drzwiami. Dodatkowo świadomość obcowania z fikcją sprawia, że obserwowane na ekranie dobro i zło bezpośrednio nas nie dotykają, przez co czujemy się względnie bezpiecznie, nawet oglądając pełną napięcia scenę. Bezpieczeństwo wynika oczywiście z przewidywalności tworów kultury popularnej, o czym pisze w Filozofii sztuki masowej Noël Carroll. Dzieła kultury popularnej, oprócz schematyczności, są nastawione na wywołanie specyficznego efektu emocjonalnego. Odbiorca z kolei, wybierając określony gatunek, informuje, jakiego stanu emocjonalnego pragnie doznać w danej sytuacji ${ }^{22}$. Podejmując decyzję, komunikuje ponadto, jakie są jego oczekiwania i preferencje.

W tym kontekście kolejny mechanizm wydaje się szczególnie interesujący. Jest nim możliwość kontaktu z takimi produkcjami popkultury, które nie poprzestają na dostarczaniu przyjemności, lecz stanowią ciekawą analizę tego, co w kulturze najnowszej najbardziej zasługuje na uwagę. Są one swoistą próbą diagnozy rzeczywistości. Sarah Cardwell, mówiąc o amerykańskiej telewizji jakościowej, podkreśla:

Amerykańska jakościowa telewizja dąży również do koncentracji na teraźniejszości, podejmując refleksję nad współczesnym społeczeństwem i krystalizując ją na nowo dzięki przywołaniu mniejszych przykładów i drobnych przypadków. „Codzienne zdarzenia”, które są treścią bardziej bezpośrednich, niejakościowych oper mydlanych, są tutaj przekształcane przez sugestię, że można je odczytać symbolicznie, refleksyjnie lub pośrednio, i odnaleźć w nich ogólniejsze prawdy o życiu lub społeczeństwie ${ }^{23}$.

Współcześnie to właśnie seriale przejęły rolę „zwierciadła przechadzającego się po gościńcu”. Agnieszka Holland w wywiadzie dla „Newsweek Polska” stwierdza:

Współczesne produkcje telewizyjne opierają się na świetnym materiale literackim, pozwalają na eksperymenty formalne. Stają się kroniką naszych czasów. XIX wiek został opisany w epickich powieściach Dostojewskiego, Tołstoja, Hugo czy Balzaca, drukowanych w odcinkach w prasie. Dzisiaj to właśnie ambitny serial pozwala

22 N. Carroll, Filozofia sztuki masowej, tłum. M. Przylipiak, Gdańsk 2011, s. 65.

23 S. Cardwell, dz. cyt., s. 137. 
przedstawić totalną wizję współczesnego świata. Nikt ostatnio nie pokazał mechanizmów polityki i problemów społeczności wielkiego miasta równie sugestywnie jak autorzy Prawa ulicy - epopei o przestępczym Baltimore ${ }^{24}$.

Podobnego zdania jest Jacek Dukaj, który w 2012 roku pisał tak:

Przesuwają się granice królestw kultury, coraz mniej miejsca mamy w życiu dla książek (...). Kiedy przed laty pisałem, iż serial telewizyjny staje się najbardziej naturalną formą opowiadania o świecie i człowieku, zastępując powieść, był to samotny głos ekscentryka. Dziś nie mam się nawet z kim spierać o tę oczywistość. Odwróciły się kierunki emanacji - to powieści upodabniają się do seriali. Pora zatem podbić stawkę. Stanę w obronie tezy silniejszej - seriale w dużej części są dla człowieka tym, czym dla ludzi średniowiecza i renesansu były moralitety ${ }^{25}$.

W świetle faktu, iż żyjemy obecnie w świecie metakultury ${ }^{26}$, szczególnie ważna jest rola, jaką odgrywa kultura popularna. Mówi ona nie tylko o rzeczywistości, która ją wyprodukowała, ale także zmusza widza do refleksji nad tym światem i sobą samym. Świadomy odbiorca potrafi wychwycić nawiązania do aktualnych problemów społecznych i odnieść je do własnej wiedzy lub własnych doświadczeń. W moim odczuciu próby takiego czytania popularnych tekstów kultury, nawet przez ludzi zupełnie niezwiązanych z jakąkolwiek krytyką medioznawczą, zdarzają się coraz częściej. Wynika to oczywiście z wyraźnej popularyzacji i rozpowszechnienia zjawiska telewizji jakościowej, która swoją formułą zmusza do uważnego oglądania, a nie tylko pobieżnego śledzenia głównej fabuły. Taki odbiór nie może być już nazywany bezrefleksyjną konsumpcją kultury masowej:

Inne aspekty mają zapewnić serialowi zaangażowanie i uznanie widowni, przykładowo złożone struktury narracyjne, skomplikowane wątki, użycie erudycyjnego, technicznego, oratorskiego, a nawet poetyckiego języka oraz dynamicznego stylu. Zostajemy wrzuceni pomiędzy sceny i pojedyncze chwile; to sugeruje bardziej rozwiniętą i kreatywną wizję oraz techniczne umiejętności, zmusza także widza do koncentracji. Ten wyższy poziom zaangażowania jest uznawany za kolejną cechę

${ }^{24}$ Cytat pochodzi z wywiadu: Ambitne seriale, z A. Holland rozm. K. Kwiatkowski, „Newsweek Polska”, 26.11.2011, http://kultura.newsweek.pl/ambitne-seriale,81355,1,1.html, dostęp: 1.03.2016.

${ }^{25}$ J. Dukaj, Serial zamiast powieści, „Filmowy Magazyn do Czytania” 2012, nr 1, s. 35.

26 „Metakultura to kultura, która mówi o innej kulturze i która nieustannie wytwarza warunki ku temu, aby komentować i projektować kolejne poziomy własnej ekspansji. Dzisiejszy świat jest właśnie w tym sensie metakulturowy, że dzięki masowym mediacjom jakikolwiek wytwór kulturowy, który się pojawia, nigdy nie jest tworzony jako odrębny element, ale już w punkcie wyjścia stanowi część symultanicznej totalności” - W.J. Burszta, W. Kuligowski, Sequel. Dalsze przygody kultury w globalnym świecie, Warszawa 2005, s. 17. 
telewizji jakościowej. W ten sposób ustawia widza w pozycji aktywnej, którą człowiek przyjmuje wtedy, kiedy wydaje opinię krytyczną. Program sam zachęca odbiorcę do interpretacji i oceny ${ }^{27}$.

Ostatnim, podanym przez Darską, powodem oglądania tego typu programów jest chęć poczucia przynależności do większej wspólnoty, jaką - szczególnie w dobie internetu - zaspokajają społeczności fanowskie. Cechuje je, wspomniany już, aktywny odbiór ulubionych tekstów kultury. Uczestnicy identyfikują się jako grupa i potrafią rozpoznać „swoich”. Skupiają się wokół różnych forów dyskusyjnych, wspólnie interpretują to, co poznali, oraz doszukują się detali i ukrytych sensów. Jak twierdzi Henry Jenkins: „Gwarantuje to, że każdy, kto zainwestuje czas i wysiłek, zyska bogatsze doświadczenie rozrywkowe" 28 . Nie sposób się z tym nie zgodzić. Dzięki takiemu odbiorowi doświadczanie ulubionej serii nie kończy się wraz z pojawieniem napisów końcowych ostatniego odcinka sezonu, lecz trwa niejednokrotnie dłużej niż sam serial.

Francuski cyberteoretyk Pierre Lévy wprowadził termin inteligencji zbiorowej, czyli konsumpcji jako procesu kolektywnego. Jest to, jak tłumaczy Jenkins, suma wiedzy posiadanej przez ogół odbiorców kultury masowej ${ }^{29}$. Oglądając seriale, uczymy się odczytywać pewne kody, dzięki znajomości których możemy pewniej poruszać się po świecie kultury popularnej. Staje się ona dla nas, jak mówi badaczka zjawiska, bardziej „otwarta i oswojona”:

Unifikacja związana z doświadczeniem bycia widzem danego serialu wspiera budowanie istotnej z punktu widzenia znoszenia granic wspólnoty kulturowej i pozwala dyskutować nie tylko o tym, co bezpośrednio widzimy w ramach rozwijającej się akcji, ale i o tym, co pojawia się w serialowym tle i niekoniecznie zostaje wyeksponowane na pierwszym planie $^{30}$.

Popularność pewnych produkcji pozwala na nawiązanie między fanami nici porozumienia. Noël Carroll w przywoływanym już opracowaniu stwierdza, że właśnie dzięki tworzeniu sprzyjających warunków do powstawania wspólnot kultura masowa będzie w dobie współczesności bardzo rozpowszechniona:

Upodobanie do sztuki łatwo dostępnej tak szybko nie zginie, ani przyjemność, jaka płynie ze wspólnego doświadczania tych samych dzieł z wieloma współobywatelami. Ludzie lubią mieć kontakt z tymi samymi dziełami sztuki, co sąsiedzi. Jest to element zjawiska, które Kant nazwał „socjalizującą rolą sztuki”. Lubimy czytać,

27 S. Cardwell, dz. cyt., s. 138.

8 H. Jenkins, dz. cyt., s. 25.

Tamże, s. 10.

${ }^{30}$ B. Darska, dz. cyt., s. 7. 
oglądać, słuchać tych samych rzeczy, a następnie o nich rozmawiać. Jest dla nas ważne, że nasi kochankowie i współpracownicy dorastali przy tych samych piosenkach i programach telewizyjnych co my. To ważny składnik wspólnoty kulturowej. Sztuka masowa niewątpliwie lepiej zaspokaja tę socjopsychologiczną potrzebę ${ }^{31}$.

Trzy funkcje seriali, istotne z punktu widzenia tworzenia się wspólnot, wyróżnia Maryla Hopfinger:

Przekazy serialowe pełnią też ważne dla wspólnoty funkcje - poznawczą (mały realizm), integracyjną (wobec różnych warstw społecznych, zróżnicowań środowiskowych, pokoleniowych, odmiennych doświadczeń), wzorcotwórczą (moc kształtowania wzorów, postaw i zachowań, etycznych i emocjonalnych) ${ }^{32}$.

Należy przypomnieć tutaj, co o roli seriali mówili Holland i Dukaj. W dobie rażącego spadku czytelnictwa, to właśnie one pełnią funkcje dawniej przypisywane literaturze. Jak pisze Wojciech Burszta: „seriale przejmują dzisiaj rolę spoiw społecznych. Seriale i ich znajomość to jest jedyne spoiwo ludzi, którzy są na równi kompetentni w treściach"33. Warto zauważyć, że szczególnie duży zasięg mają programy amerykańskie i brytyjskie. Bez względu na szerokość geograficzną odbiorcy stają się uczestnikami tej samej gry analityczno-interpretacyjnej. Nawet bariera językowa coraz częściej przestaje być przeszkodą, a używane zwroty i kody kulturowe zaczynają być rozumiane bez większego problemu (znajomość języka w stopniu komunikatywnym do pełnego odbioru nie wystarczy - tak się zresztą dzieje nie tylko w wypadku tego tekstu kultury) ${ }^{34}$.

${ }^{31}$ N. Carroll, dz. cyt., s. 23.

32 M. Hopfinger, Seriale telewizyjne [w:] tejże, Literatura i media po 1989 roku, Warszawa 2010 , s. 239.

${ }^{33}$ Cytat pochodzi z rozmowy: $O$ nowej jakości $w$ amerykańskim serialu telewizyjnym, z W.J. Bursztą rozm. E. Kasperek, S. Wojciechowska, eczaskultury.pl, 21.03.2012, http://e.czaskultury.pl/czytanka/rozmowy/990-o-nowej-jakosci, dostęp: 18.03.2016.

${ }^{34}$ Tu pojawia się jeszcze jeden powód oglądania seriali - nauka angielskiego. Powszechnie znaną praktyką służącą nabywaniu umiejętności językowych, wymagającą samodzielnych ćwiczeń, było czytanie znanych powieści w oryginale. Sama, ucząc się języka, sięgałam po klasykę brytyjskiego kryminału. Niedawno spotkałam się z tym, że lektorzy polecają oglądanie seriali amerykańskich oraz brytyjskich w celach edukacyjnych, ponieważ pozwalają one na obserwację języka w jego „naturalnym środowisku”. Dodatkowo serial umożliwia dłuższy kontakt (niż to się dzieje na przykład w wypadku filmu) z postaciami, przez co odbiorca może się osłuchać $\mathrm{z}$ różnymi akcentami. Owa nauka przez zabawę ujawnia korzystny aspekt śledzenia kolejnych odcinków ulubionych serii. Jednak takie „zapatrzenie” w zachodnią kulturę ma również skutek negatywny, jaki można upatrywać w przyjmowaniu za swoje tamtejszych postaw i wartości. O ile bowiem świadomość występowania i zdolność ich dostrzeżenia w różnego typu tekstach kultury są cenną umiejętnością, o tyle zaszczepianie ich do naszej rzeczywistości już za nią uznane być nie może. Współcześnie w dobie globalizacji, która coraz częściej staje się synonimem amerykanizacji, jest to chyba nieuniknione. 
W odniesieniu do wspólnototwórczej roli serialu warto dodać jeszcze jeden aspekt łączący ten tekst kultury z literaturą właśnie. W trakcie lektury ulubionej serii powieściowej z utęsknieniem czekało się na kolejne tomy, które po przeczytaniu odstawiało się na półkę obok poprzednich. W ostatnim czasie pojawiła się możliwość zakupu całych sezonów seriali wydanych w formie DVD. To zupełnie zmienia charakter serialu, łączy się z nowym stylem odbioru. Wcześniej porównywano go z czytaniem powieści odcinkowej drukowanej w gazetach, z którego to gatunku się wywodził. Teraz jednak wydaje się, że znacznie bliżej jest mu do serii powieściowych, których poszczególne rozdziały stanowiłyby odcinki, a kolejne tomy - sezony. Tak komentuje to Wojciech Burszta:

No właśnie, pojawia się to zjawisko boxów. Jest to niewątpliwie nowa jakość w tym sensie, że to są jedyne produkcje, które znowu ogląda się zbiorowo, najczęściej w gronie rodziny, w każdym razie nie w samotności. Z socjologicznego punktu widzenia jest to niezwykle istotne, że jednoczy widzów przed telewizorem. To są takie wspólnoty kompetencji, które powstają w obrębie rodziny i, szerzej, także w obrębie rozmaitych grup towarzyskich, które są oznajmione [sic! - A.L.] właśnie w tych kodach związanych z poszczególnymi filmami, tak jak kiedyś były wspólnoty, które potrafiły te kody czerpać na przykład $\mathrm{z}$ literatury ${ }^{35}$.

Taki format oddaje również większą władzę w ręce odbiorcy. Już nie musi on bowiem czekać tydzień na kolejny odcinek, może za to, jak w wypadku rozdziałów książki, sam zadecydować, z iloma epizodami zapozna się podczas lektury.

Warto zwrócić uwagę na jeszcze jeden aspekt łączący telewizję z literaturą bardzo podobne style odbioru. Amanda Lotz, która odwołuje się do stwierdzenia Horacego Newcomba ${ }^{36}$, zauważa, że telewizja naśladuje praktykę księgarni, wprowadzając konieczność opłat za posiadanie niektórych treści (programy wydane na DVD, pobieranie z serwisu iTunes). Z kolei konieczność regularnego płacenia za dostęp do premiowanych kanałów telewizji kablowej przypomina prenumeratę czasopism, bezpłatny zaś dostęp do wyemitowanych na życzenie programów przywodzi na myśl sposób działania bibliotek ${ }^{37}$. Wymienione wyżej zjawiska wpływają na dezaktualizację kategorii efemeryczności przypisywanej do tej pory produktom telewizyjnym.

Analizując współcześnie zachodzące przemiany społeczne, nie sposób pominąć tego, co przynosi nam popkultura. Doskonale obrazuje to stwierdzenie Henry'ego Jankinsa:

${ }^{35}$ O nowej jakości..., dz. cyt.

36 Por. „telewizja funkcjonuje jak księgarnia, stoisko z gazetami czy biblioteka”, cyt. za: A. Lotz, Zrozumieć telewizję u progu postsieci [post-network era], tłum. M. Poks [w:] Zmierzch telewizji?..., dz. cyt., s. 95.

37 Tamże. 
Każdy z nas tworzy swoją własną osobistą mitologię z części oraz fragmentów informacji wyłuskanych ze strumienia mediów i przekształconych w zasoby, dzięki którym nadajemy sens naszemu życiu codziennemu ${ }^{38}$.

Opowieści narracyjne od zawsze stanowiły podstawowe narzędzie w budowaniu własnej świadomości i tożsamości. Przez wieki zmieniały się tylko formy i kanały, jakimi ludzie się nimi dzielili. W dzisiejszych czasach najczęściej przyjmują formę seriali. Nadają się one do tego doskonale, ponieważ pozwalają odbiorcy nie tylko na rozrywkę, ale także stają się czynnikiem zmuszającym do refleksji nad samym sobą i światem, w którym żyjemy. Rozpowszechnienie popularnych serii na skalę międzynarodową sprawia, że kody kulturowe, dotyczące na przykład stereotypu pewnych postaci czy zjawisk, nabierają uniwersalnych znaczeń. Najlepszym tutaj podsumowaniem będą słowa Anny Nacher, która mówi, że: „Narracje seriali telewizyjnych stanowią repertuar biograficznych skryptów, za pomocą których opowiadamy sobie własne życie"39.

\section{Bibliografia}

Ambitne seriale, z A. Holland rozm. K. Kwiatkowski, „Newsweek Polska”, 26.11.2011, http://kultura.newsweek.pl/ambitne-seriale,81355,1,1.html, dostęp: 1.03.2016.

Burszta W.J., Kuligowski W., Sequel. Dalsze przygody kultury w globalnym świecie, Warszawa 2005.

Cardwell S., Czy telewizja jakościowa jest dobra? Różnice gatunkowe, oceny oraz ktopotliwa kwestia krytycznego osadu, tłum. D. Kuźma [w:] Zmierzch telewizji? Przemiany medium. Antologia, red. T. Bielak, M. Filiciak, G. Ptaszek, Warszawa 2011.

Carroll N., Filozofia sztuki masowej, tłum. M. Przylipiak, Gdańsk 2011.

Darska B., Zamiast wstępu [w:] tejże, To nas pociaga! O serialowych antybohaterach, Gdańsk 2012.

Dukaj J., Serial zamiast powieści, „Filmowy Magazyn do Czytania” 2012, nr 1, s. 34-49.

Dunin K., Tomasik K., 101 seriali [w:] Seriale. Przewodnik Krytyki Politycznej, red. Zespół Krytyki Politycznej, Warszawa 2011.

Grębowiec J., Lewicki A., Wstęp [w:] Seriale z różnych stron, red. A. Lewicki, J. Grębowiec, Wrocław 2015.

Hopfinger M., Seriale telewizyjne [w:] tejże, Literatura i media po 1989 roku, Warszawa 2010.

${ }^{38}$ H. Jenkins, dz. cyt., s. 9.

39 A. Nacher, Serial 2.0 - model do sktadania [w:] Post-soap..., dz. cyt., s. 226. 
Jenkins H., Kultura konwergencji. Zderzenie starych i nowych mediów, tłum. M. Bernatowicz, Warszawa 2006.

Lebioda J., Najdroższe seriale wszechczasów. Zaskakująca czołówka, http://life. forbes.pl/ranking-najdrozszych-seriali-w-historii,artykuly, 194157,1,1.html, dostęp: 1.03.2016.

Lotz A., Zrozumieć telewizję u progu postsieci [post-network era], tłum. M. Poks [w:] Zmierzch telewizji? Przemiany medium. Antologia, red. T. Bielak, M. Filiciak, G. Ptaszek, Warszawa 2011.

Nacher A., Serial 2.0 - model do sktadania [w:] Post-soap. Nowa generacja seriali telewizyjnych a polska widownia, red. M. Filiciak, B. Giza, Warszawa 2011.

O nowej jakości $w$ amerykańskim serialu telewizyjnym, z W.J. Bursztą rozm. E. Kasperek, S. Wojciechowska, eczaskultury.pl, 21.03.2012, http://e.czaskultury. $\mathrm{pl} /$ czytanka/rozmowy/990-o-nowej-jakosci, dostęp: 18.03.2016.

Piątkowski W., Marketing telewizji, czyli dlaczego tylko niektóre seriale odnoszą sukces [w:] Post-soap. Nowa generacja seriali telewizyjnych a polska widownia, red. M. Filiciak, B. Giza, Warszawa 2011.

Thompson R.J., Television's Second Golden Age: From „Hill Street Blues” to „ER”, New York 1996.

Włodarczyk A., Wptyw realny czy wyobrażony? Fanowskie poczucie wptywu na seriale "Sherlock” $i$ "Nie z tego świata” [w:] Seriale w kontekście kulturowym: gatunki, konwergencja, recepcja, red. A. Krawczyk-Łaskarzewska, A. Naruszewicz-Duchlińska, P. Przytuła, Olsztyn 2014.

Wysocki G., Epidemia chronicznej serialozy, dwutygodnik.pl 2011, nr 6, http:// www.dwutygodnik.com/artykul/2395-epidemia-chronicznej-serialozy.html, dostęp: 30.03.2016. 